\title{
Biological and population parameters of Tiger Shark Galeocerdo cuvier, landed in Tanjung Luar, West Nusa Tenggara
}

\author{
Irwan Jatmiko*, and Suciadi Catur Nugroho \\ Research Institute for Tuna Fisheries, Denpasar, Bali, Indonesia - 80224
}

\begin{abstract}
Tiger shark is one of the important catch for small scale fisheries in West Nusa Tenggara. It is considered nearly threatened according the IUCN, thus information regarding to its estimated population is needed for conservative efforts. This study aimed to estimate the biological and population parameters of the tiger shark in Indonesia. Length data were collected from March to December 2018 in Tanjung Luar Port, West Nusa Tenggara. The length-weight relationship was calculated using equation $\mathrm{W}=\mathrm{a} \mathrm{L}^{\mathrm{b}}$. Electronic length-frequency analysis (ELEFAN) in R Statistics with package "TropFishR" was used to estimate the population parameter. Length converted catch curve (LCCC) analysis was used to estimate the total mortality of the species. The results showed the length-weight relationship for combined sex, male and female was similar to the equation $\mathrm{W}=0.000001 \mathrm{~L}^{3.15}$. The growth pattern for this species was positive allometric which means that the growth of weight is faster than its length. Total mortality was estimated at $0.33 / \mathrm{yr}$, with natural and fishing mortality of $0.16 / \mathrm{yr}$ and $0.17 / \mathrm{yr}$, respectively. The results from this study should be able to provide the basic information to support fisheries management of tiger sharks in Indonesia.
\end{abstract}

\section{Introduction}

Indonesia is one of the important players in shark fisheries in the world, especially shark fins. From 2000 to 2011, the annual average export of Indonesian shark fins reached 1,235 tons with a value reaching $\$ 10$ million [1]. Some of the fish landing sites that lands sharks are the ports of Benoa, Bali, the port of Cilacap, Central Java and the port of Tanjung Luar, West Nusa Tenggara. In Benoa and Cilacap, sharks are one of the bycatches of tuna longline fisheries that targeting tuna catches [2,3]. While in Tanjung Luar, sharks are one of the main catches for traditional fishermen which using set longline and drifting longline $[3,4]$.

The exploitation of sharks has been an important issue in global fishery management due to their biological characteristics $[5,6]$. These group of that are very susceptible to overfishing conditions because they have different life cycles. Some of them are slow growth rates and reproduction processes that are also slow and produce little juvenile [7]. One type of shark

"Corresponding author: irwan.jatmiko@gmail.com 
that is important for small-scale fishermen in West Nusa Tenggara (NTB) is the tiger shark (Galeocerdo cuvier). According to the International Union for Conservation of Nature (IUCN) [8], the current conservation status of this species is near threatened (NT) which means that this species is possible to be threatened in near future.

One aspect to support fisheries management is to know the age and growth of fish species [9]. Information of age and growth can be used to estimate recruitment, life span, and mortality which can be used to determine the level of exploitation of fish stocks [10]. Some calcified parts in fish can be used to determine the age of fish, namely ear stones (otolith), spine, and vertebrae $[11,12,13]$. However, sharks species do not have otolith to determine their age [14]. Moreover, the analysis of calcified parts is expensive and require a significant amount of time to process [15]. An alternative method that can be used to determine the age and growth of fish species is using long frequency analysis [16]. This study aimed to estimate the biological and population parameters of the tiger shark in Indonesia.

\section{Materials and Methods}

Data collection was carried out by measuring the total length (TL) with $1 \mathrm{~cm}$ accuracy and determining the sex of the tiger shark at Tanjung Luar Fish Landing Port (Figure 1), West Nusa Tenggara (NTB) from March to December 2018. We aimed to cover a one-year period of the catch, but the project was started in March. The tiger shark landed was caught by fishing rods that operated in the waters south of NTB and East Nusa Tenggara (NTT). The process of identifying the tiger shark was done by referring to the shark identification book from [17] Campagno (1998) and [18] White et al. (2006).

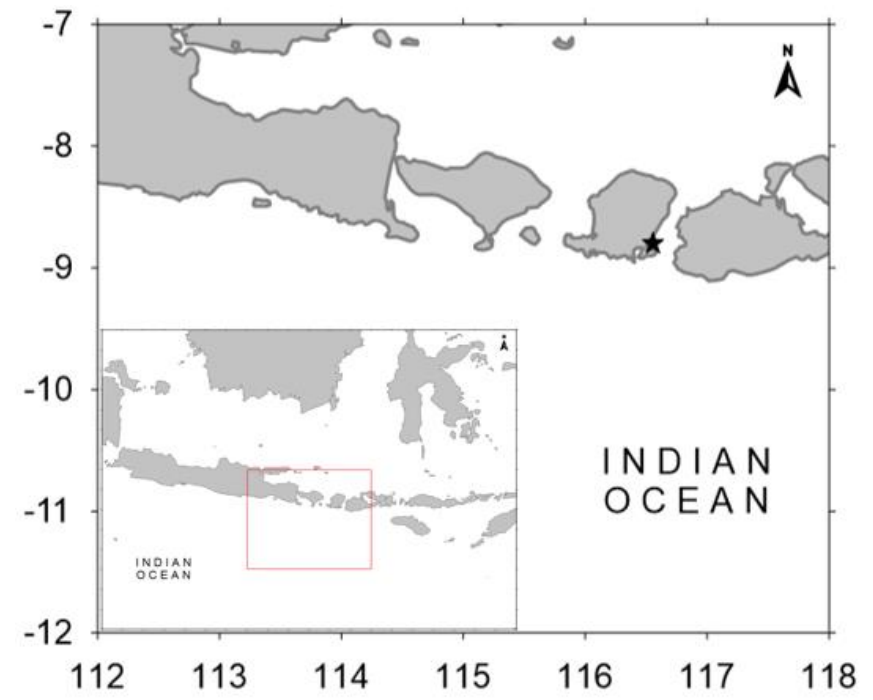

Fig. 1. The study site in Tanjung Luar Fish Landing Port (marked with star), West Nusa Tenggara (NTB).

The length-weight relationships were calculated using the equation:

$$
W=a L^{b}
$$

Where $W$ is body weight $(\mathrm{kg}), L$ is fork length $(\mathrm{cm}), a$ is a coefficient related to body form and $b$ is an exponent indicating fish growth [19]. The values of the exponent $b$ provide 
information on fish growth. When $b=3$, the increase in weight is isometric. When the value of $b$ is other than 3 , the weight increase is allometric. In other words, positive allometric if $b>3$, negative allometric if $b<3$. The null hypothesis of isometric growth $\left(H_{0}: b=3\right)$ was tested using $t$-test [20].

Linf and K population parameters are calculated by Electronic Length Frequency Analysis (ELEFAN) analysis in the R statistics program with the "TropFishR" package. ELEFAN analysis can be used to calculate $\operatorname{Linf}$ and $\mathrm{K}$ values to estimate growth parameters by the formula from Mildenberger et al. (2017) [21]:

Cuvier_ELEFAN $=$ ELEFAN $(x=$ Cuvier_data, Linf_range $=$ seq (min, max, ran $), K$ _range

$$
=\operatorname{seq}(\min , \max , \operatorname{ran}))
$$

Where $\mathrm{x}=$ list of information consisting of the length of the temptation and the time to be caught; Linf_range = vector value to determine the Linf value consisted of minimum, maximum and range values; $K$ range = vector value to determine the value of $K$ which consists of the minimum, maximum and range values.

The theoretical age at a length of $0 \mathrm{~cm}\left(t_{0}\right)$ was calculated using the formula from Pauly (1980) [22] as follows:

$$
\log \left(-t_{0}\right)=-0,3922-0,2752 \log L \infty-1,038 \log K
$$

where $\mathrm{t}_{0}=$ theoretical age at a length of $0 \mathrm{~cm} ; \mathrm{L} \infty=$ infinity length; $\mathrm{K}=$ growth rate of the shark. The determination of tiger shark total mortality used a length-converted catch curve analysis from Pauly (1983) [23].

\section{Results}

\subsection{Length frequency and length-weight relationships}

A total of 696 tiger shark were measured in total length, consisting of 335 males and 361 females. The average total length of tiger sharks was $248.4 \mathrm{~cm}$ with a range of $117-400 \mathrm{~cm}$ (Figure 2). The length-weight relationship for combined sex, male and female was similar to the equation showed in Table 1 and Figure 3.

Table 1. The parameters for length-weight relationships of tiger shark (G. cuvier) landed in Tanjung

\begin{tabular}{|c|c|c|c|}
\hline Parameters & Combined sex & Female & Male \\
\hline$a$ & 0.000001 & 0.000001 & 0.000001 \\
\hline$b$ & 3.15 & 3.16 & 3.15 \\
\hline$R^{2}$ & 0.91 & 0.92 & 0.90 \\
\hline $\begin{array}{l}\text { Growth } \\
\text { pattern }\end{array}$ & $\begin{array}{l}\text { Allometric } \\
\text { positive }\end{array}$ & $\begin{array}{l}\text { Allometric } \\
\text { negative }\end{array}$ & $\begin{array}{l}\text { Allometric } \\
\text { positive }\end{array}$ \\
\hline
\end{tabular}
Luar Port, West Nusa Tenggara in 2018. 

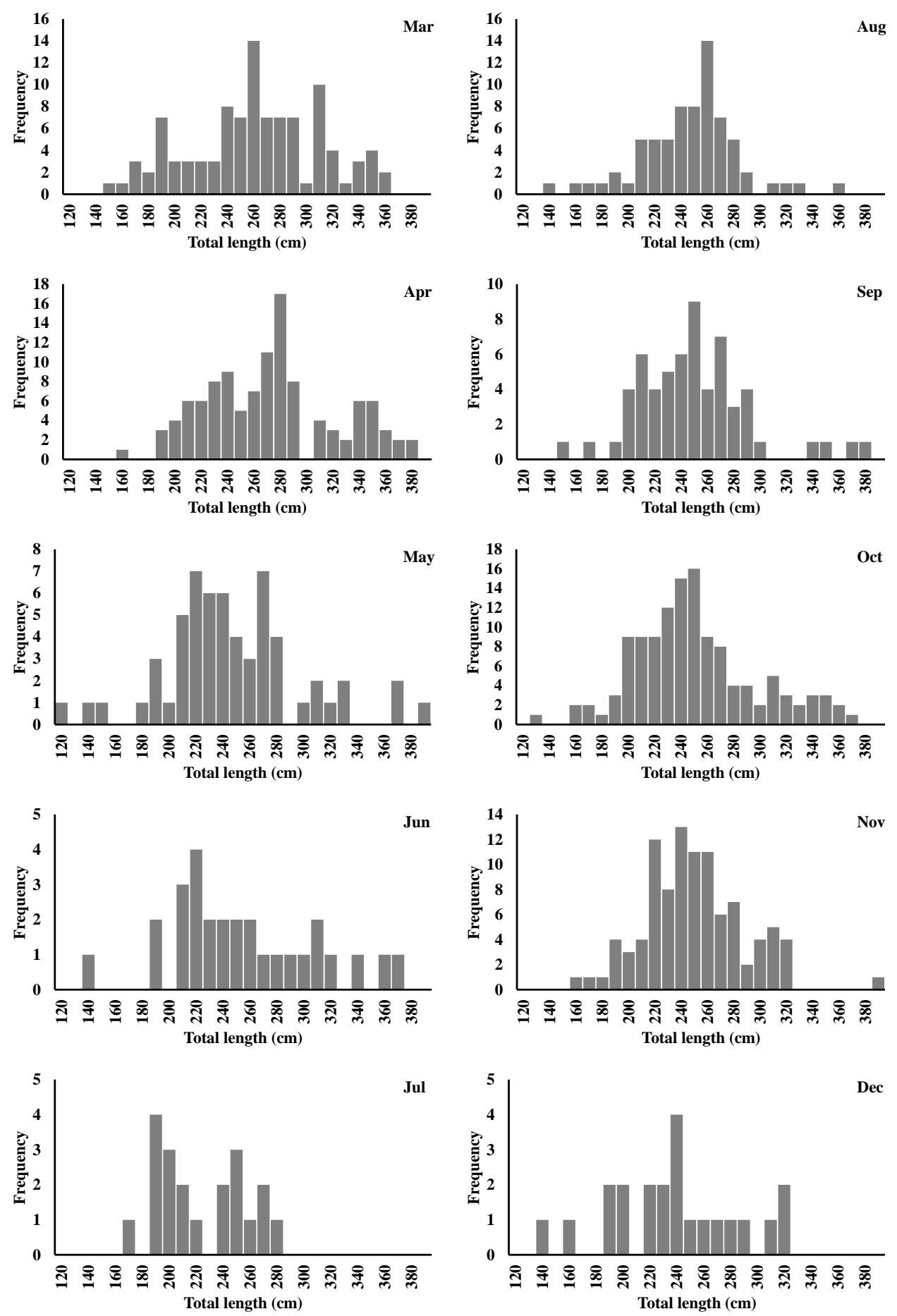

Fig. 2. Total length (cm) of tiger shark (G. cuvier) landed in Tanjung Luar Port, West Nusa Tenggara in 2018. Value at $x$ axis is upper limit of length class with $10 \mathrm{~cm}$ intervals. 


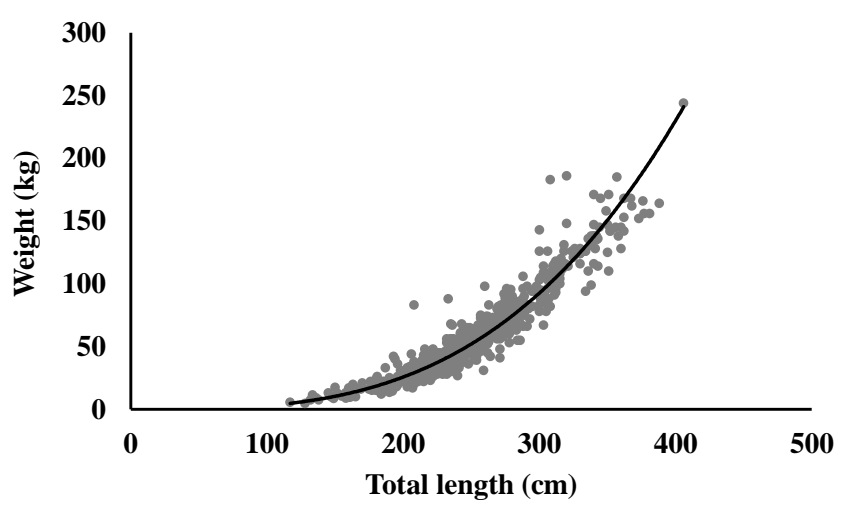

Fig. 3. Length-weight relationships (combined sex) of tiger shark (G. cuvier) landed in Tanjung Luar Port, West Nusa Tenggara in 2018.

\subsection{Age, growth and mortality}

Von Bertalanffy growth curve fo male shark (G. cuvier) obtained infinity length value (Linf) of $379 \mathrm{~cm}$ with growth coefficient $(K)$ of $0.12 / y r s$ and theoretical age at length $0 \mathrm{~cm}\left(t_{0}\right)$ $0.72 y r s$. For female shark, $\operatorname{Linf}=381 \mathrm{~cm}, K=0.15 / y r s$ and $t_{0}=-0.57 y r$. Whereas for combined sex obtained $\operatorname{Linf}=380 \mathrm{~cm}, K=0.10 / y r$ and $t_{0}=-0.86$ yrs (Figure 4). The total mortality $(\mathrm{Z})$ of tiger shark (G. cuvier) derived from the value of the linearity given gives a result of $0.33 / y r$ (Figure 5).

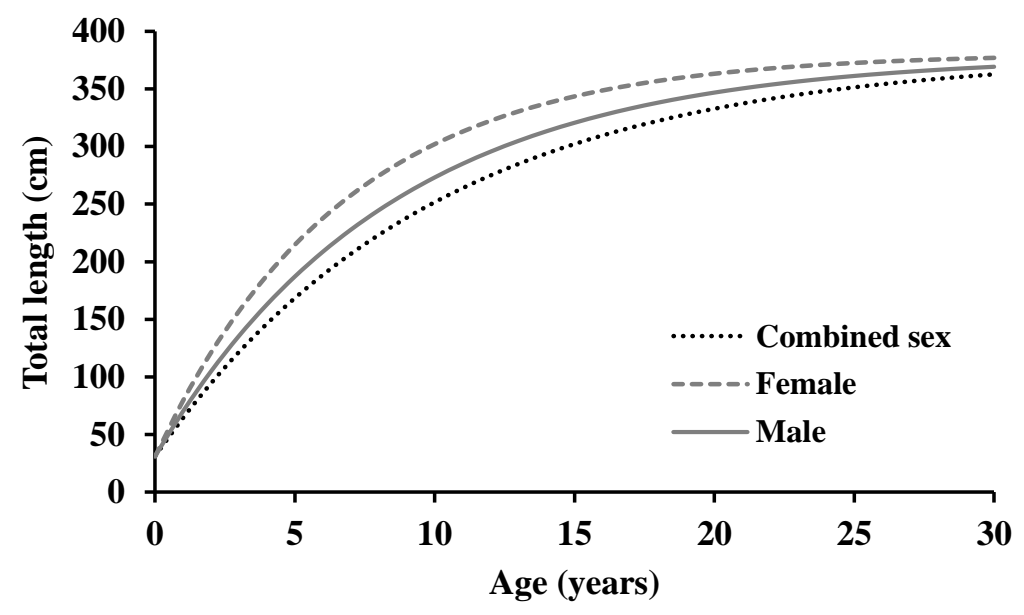

Fig. 4. Von Bertalanffy growth curve of tiger shark (G. cuvier) male (Linf $=379 \mathrm{~cm} ; K=0.12 / y r s ; t_{0}=-$ $0.72 y r \mathrm{~s})$, female $\left(\operatorname{Linf}=381 \mathrm{~cm} ; K=0.15 / y r \mathrm{~s} ; t_{0}=-0.57 y r \mathrm{~s}\right)$ and combined sex (Linf $=380 \mathrm{~cm}$; $\left.K=0.10 / y r s ; t_{0}=-0.86 y r s\right)$. 


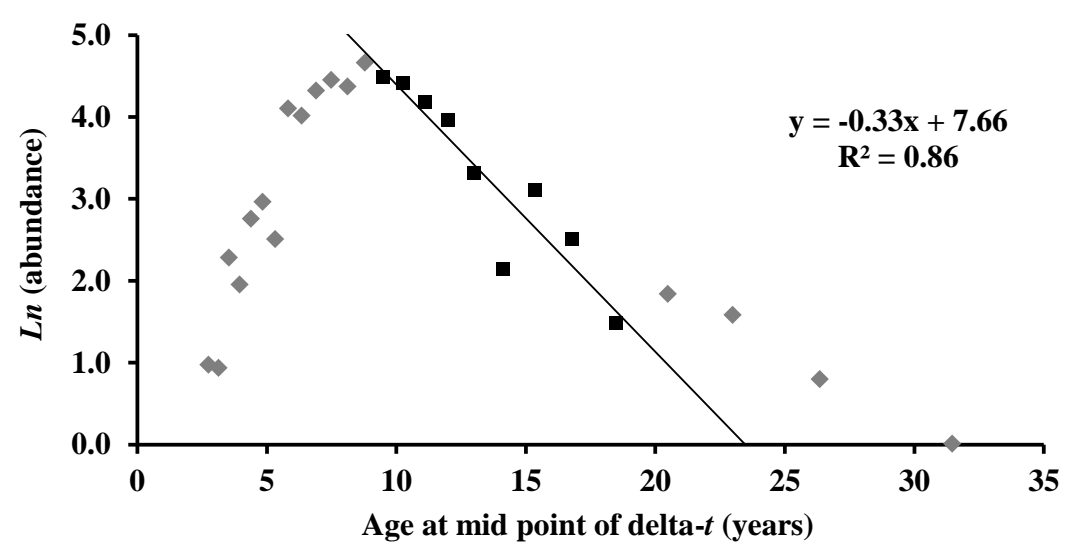

Fig. 5. Total mortality (Z) of tiger shark (G. cuvier) landed in Tanjung Luar Port, West Nusa Tenggara in 2018 .

\section{Discussion}

In general, the length of male tiger shark is longer than that of females. The average length of male tiger shark is $250.4 \mathrm{~cm}$ while the average length of female tiger shark was only 246.4 $\mathrm{cm}$. A similar result also found from [24] studies in the same water where the average length for male is $244.5 \mathrm{~cm}$ and for female is $241.5 \mathrm{~cm}$.

For the length-weight relationship, it showed that there were similar parameters among male, female and combined sex. The growth pattern for all of them was allometric positive. It means that the growth of its weight is faster than its length. This condition may occur due to seasonal variations, environmental condition and food availability $[15,25]$.

The different conditions occurred for the infinity length (Linf) of this species where female tiger sharks are longer than male tiger sharks. The infinity length (Linf) of the female tiger shark was $381 \mathrm{~cm}$ longer than the male tiger shark which only reaches $379 \mathrm{~cm}$ infinity length. For combined sex, the infinity length (Linf) was $380 \mathrm{~cm}$. A similar condition also occurred in North-west Atlantic, USA, that the female had longer Linf with $340 \mathrm{~cm}$ compared to male Linf with only $330 \mathrm{~cm}$ [26] (Table 2).

The growth rate $(\mathrm{K})$ of tiger sharks is $0.15 / \mathrm{yr}, 0.12 / \mathrm{yr}$ and 0.10 for female, male, and combined, respectively. This is similar to the growth rate of this species in several waters $[24,26,27,28,29]$. The highest growth rate $(K)$ for this species occurred in Hawaii, USA with $0.31 / \mathrm{yr}$. According to research, tiger sharks do have a very slow growth rate similar to other shark species [25]. Some other shark species that have a slow growth rate are silky sharks with $K=0.08 /$ year [30], blue sharks with $K=0.12 /$ year [31] and bull sharks with $K=$ $0.07 /$ year [32]. The difference in growth rate possibly affected by temperature and food availability [33]. 
Table 2. Growth parameters of tiger sharks (Galeocerdo cuvier) from several locations.

\begin{tabular}{|c|c|c|c|c|c|c|}
\hline Location & Sex & $\operatorname{Linf}(\mathrm{cm} K$ & $(/ \mathbf{y r})$ & to (yrs) & Methods & Reference \\
\hline $\begin{array}{l}\text { West Nusa } \\
\text { Tenggara, Indonesia }\end{array}$ & Combined & 420 & 0.26 & -0.02 & FISAT II & $\begin{array}{l}\text { Chodrijah et } \\
\text { al. (2018) }\end{array}$ \\
\hline $\begin{array}{l}\text { East Coast, } \\
\text { Australia }\end{array}$ & Combined & 403 & 0.08 & - & Vertebrae & $\begin{array}{l}\text { Holmes } \\
(2015)\end{array}$ \\
\hline Hawaii, USA & Combined & 406 & 0.31 & - & $\begin{array}{l}\text { Mark- } \\
\text { recapture }\end{array}$ & $\begin{array}{l}\text { Meyer et al . } \\
\text { (2014) }\end{array}$ \\
\hline North-west Atlantic, & Female & 340 & 0.12 & - & Radio- & Kneebone et \\
\hline USA & Male & 330 & 0.13 & - & carbon & al. (2008) \\
\hline South Africa & Combined & 400 & 0.20 & - & $\begin{array}{l}\text { Back- } \\
\text { calculation }\end{array}$ & $\begin{array}{l}\text { Wintner \& } \\
\text { Dudle (2000) }\end{array}$ \\
\hline $\begin{array}{l}\text { West Nusa } \\
\text { Tenggara, Indonesia }\end{array}$ & $\begin{array}{l}\text { Female } \\
\text { Male } \\
\text { Combined }\end{array}$ & $\begin{array}{l}381 \\
379 \\
380\end{array}$ & $\begin{array}{l}0.15 \\
0.12 \\
0.10\end{array}$ & $\begin{array}{l}-0.57 \\
-0.72 \\
-0.86\end{array}$ & TropFishR & $\begin{array}{l}\text { This study } \\
\text { (2019) }\end{array}$ \\
\hline
\end{tabular}

With the characteristics of slow growth $(k=0.10-0.15 / y r)$, like other types of sharks $[34,35]$, the tiger sharks population was vulnerable to overfishing. Like other sharks, tiger sharks displayed slow growth in their life history. Therefore, fishermen need to allow them to grow and spawn to maintain their population. Several actions need to be conducted in order to maintain the sustainability of this species such as time-series length-frequency monitoring and stock assessment studies.

This research was funded from the research fund of the Research Institute for Tuna Fisheries (RITF) in 2018. The authors thanked Mr. Galih Rakasiwi for helping in the data collection process of this research.

\section{References}

1. F. Dent and S. Clarke, State of the global market for shark products. (Food and Agricultural Organization, Roma, 2015).

2. I. Jatmiko, B. Nugraha and F. Satria, Marine Fisheries 6, 1 (2015).

3. Fahmi and Dharmadi, African Journal of Marine Science 37, 259 (2015).

4. A.A. Sentosa, N. WIdarmanto, N.N. Wiadnyana and F. Satria, Jurnal Penelitian Perikanan Indonesia 22, 105. (2016).

5. V.F. Gallucci, I.G. Taylor and K. Erzini, Canadian Journal of Fisheries and Aquatic Sciences 63, 931 (2006).

6. J.A. Musick, G. Burgess, G. Cailliet, M. Camhi and S. Fordham, Fisheries 25, 9 (2000).

7. J.M. Hoenig and S.H. Gruber, Life history patterns in the elasmobranchs: implications for fisheries management. In H.L. Pratt Jr., S.H. Gruber and T. Taniuchi (Ed.), Elasmobranchs as living resources: advances in biology, ecology, systematics and status of the fisheries. U.S. Dep. Commer., NOAA Tech. Rep. NMFS 90. (1990).

8. International Union for Conservation of Nature (IUCN), The IUCN Red List of threatened species. Version 2017-3. www.iucnredlist.org/details/161633/0. 2018.

9. M.C. Quist and D.A. Isermann, Age and growth of fishes: principles and techniques. (American Fisheries Society, Maryland, 2017). 
10. S. Ortega-Garcia, C. Sepulveda, S. Aalbers, U. Jakes-Cota and S. Rodriguez, Fishery Bulletin 115, 117 (2017).

11. I. Jatmiko, J. Haddy and M. Williams, Indonesian Fisheries Research Journal 19, 47 (2013).

12. J.D. Filmalter, O.L.F. Weyl and W. Sauer, African Journal of Marine Science 31, 271 (2009).

13. C.A. Simpfendorfer, Environmental Biology of Fishes 36, 233. (1993).

14. C.J. Duffin, Fish otolith and folklore: A survey (Taylor \& Francis, Ltd., Oxfordshire, 2007).

15. M. King, Fisheries biology, assessment and management, 2nd edition (Blackwell Publishing Ltd, Oxford, 2010).

16. J. Schnute and D. Fournier, Canadian Journal of Fisheries and Aquatic Sciences 37, 1337. (2011).

17. L.J.V. Campagno, Sharks of the world. An annotated and illustrated catalogue of shark species known to date. (Food and Agricultural Organization, Roma, 1984).

18. W.T. White, P.R. Last, J.D. Stevens, G.K. Yearsley, Fahmi and Dharmadi, Economically important sharks and rays of Indonesia (Hiu dan pari yang bernilai ekonomis penting di Indonesia. (Australian Centre for International Agricultural Research, Canberra, 2006).

19. W.E. Ricker, Growth rate and models In: W.S. Hoar, D.J. Randall and J.R. Brett (Eds.): Fish Physiology. Vol. III. Bioenergetics and Growth. (Academic Press, Cambridge, Massachusetts, 1979).

20. G.J. Morey, E. Moranta, A. Massuti, M. Grau, F. Linde, F. Riera and B. Morales-Nin Fisheries Research 62, 89 (2003).

21. T.K. Mildenberger, M.H. Taylor and M. Wolff, Tropical Fisheries Analysis with R: Package "TropFishR” Version 1.14. (CRAN R-project, 2017).

22. D. Pauly, J. Cons. Int. Explor. Mer 39, 175. (1980).

23. D. Pauly, Some simple methods for the assessment of tropical fish stocks FAO Fish. Tech. Pap (Food and Agricultural Organization, Roma, 1983).

24. U. Chodrijah, A.A. Sentosa and Prihatiningsih, Jurnal Penelitian Perikanan Indonesia 24, 253 (2018).

25. T.B. Li, C.P. Wang and Y.S. Zhang, Journal of the Atmospheric Sciences 60, 2119. (2003).

26. C.G. Meyer, J.M. O’Malley, Y.P. Papastamatiou, J.J. Dale, M.R. Hutchinson, J.M. Anderson, M.A. Royer and K.N. Holland, PLoS ONE 9, e84799, doi:10.1371/ journal.pone.0084799 (2014).

27. B.J. Holmes, V.M. Paddemors, A.N. Gutteridge, P.T. Geraghty, R.W.K. Chan, I.R. Tibbetts and M.B. Bennett, Journal of Fish Bilogy 87, 422 (2015).

28. J. Kneebone, L.J. Natanson, A.H. Andrews and W.H. Howell, Mar. Bio. 154, 423 (2008).

29. S.P. Wintner and S.F.J. Dudley, Mar. Freshwater Res. 51, 43 (2000).

30. S.J. Joung, C.T. Chen, H.H. Lee and K.M. Liu, Fisheries Research 90, 78 (2008).

31. K.A. Jolly, C.D. Silva and C.G. Attwood, African Journal of Marine Science 35, 99 (2013).

32. S. Branstetter and R. Stiles, Environmental biology of fishes 20, 169 (1987). 
33. L.Q. Zeng, C. Fu and S.J. Fu, Comparative Biochemistry and Physiology Part A: Molecular \& Integrative Physiology 217, 26-34.

34. L. Baje, J.J. Smart, A. Chin, W.T. White and C.A. Simpfendorfer, PLoS ONE 13, 1 (2018).

35. B.M. D'Alberto, A. Chin, J.J. Smart, L. Baje, W.T. White and C.A. Simpfendorfer, Marine and Freshwater Research 68, 1118 (2017). 